\title{
Dating of Hydrothermal Mineralization in Active Hydrothermal Fields in the Southern Mariana Trough
}

\author{
Jun-ichiro Ishibashi, Kazuhiko Shimada, Fumihiro Sato, Ai Uchida, Shin \\ Toyoda, Asako Takamasa, Shun'ichi Nakai, Hironobu Hyodo, Keiko Sato, \\ Hidenori Kumagai, and Kei Ikehata
}

\begin{abstract}
Ages of sulfide and sulfate mineralized samples collected from active hydrothermal fields in the Southern Mariana Trough were determined. In addition to samples collected from active and inactive chimneys, and sulfide breccia during dive expeditions, massive sulfide ores obtained by shallow drilling were studied. We applied ${ }^{230} \mathrm{Th} /{ }^{234} \mathrm{U}$ radioactive disequilibrium dating technique to sulfide minerals, as the collected mineralized samples were dominated by marcasite, pyrite and sphalerite. In addition, electron spin resonance (ESR) dating was applied to a few barite-rich samples, for comparison purpose. A laser step heating ${ }^{39} \mathrm{Ar}-{ }^{40} \mathrm{Ar}$ dating of the basement volcanic rock samples was also attempted.

Sulfide chimneys and ores collected from a hydrothermal mound located beside the spreading axis range in age from $<100$ to 3,520 years old, without notable hiatus. The growth rate of the massive sulfide ore body is calculated to be $0.12-1.5 \mathrm{~mm} \mathrm{year}^{-1}$ based on results of the core samples. This age range is comparable for those previously reported for giant hydrothermal mounds of a few $100 \mathrm{~m}$ in diameter. These results suggest $>1,000$ years of continuous hydrothermal activity would be necessary for the formation of a massive sulfide deposit.

Sulfide chimneys and breccia collected from two hydrothermal fields located on an offaxis knoll are up to 9,000 years old. Sulfide breccia collected from an active site on the spreading axis are 2,740 and 7,190 years old. Geophysical studies provided evidence for abundant magma supply in the Southern Mariana Trough, which would have fueled hydrothermal activities in this area for long duration. While geophysical evidence for crustal velocity anomaly below the off-axis knoll suggests mineralization at the off-axis sites is considered to be in the late-stage of the hydrothermal activity, the discrete ages from the on-axis site might reflect episodic hydrothermal activities related to diking events proposed by geophysical and geological studies.
\end{abstract}

The online version of this chapter (doi:10.1007/978-4-431-54865-2_23) contains supplementary material, which is available to authorized users.

J.-i. Ishibashi $(\bowtie) \bullet K$. Shimada

Faculty of Sciences, Kyushu University, Fukuoka, Japan

e-mail: ishibashi.junichiro.779@m.kyushu-u.ac.jp

F. Sato $\bullet$ A. Uchida $\bullet$ S. Toyoda $\bullet$ H. Hyodo

Okayama University of Science, Okayama, Japan

A. Takamasa

Earthquake Research Institute, The University of Tokyo, Tokyo, Japan

National Institute of Radiological Sciences, Chiba, Japan

S. Nakai

Earthquake Research Institute, The University of Tokyo, Tokyo, Japan

\section{K. Sato}

Institute for Research on Earth Evolution (IFREE), Japan Agency for Marine-Earth Science and Technology (JAMSTEC), Yokosuka, Japan

Research and Development (R\&D) Center for Submarine Resources, Japan Agency for Marine-Earth Science and Technology (JAMSTEC), Yokosuka, Japan

Okayama University of Science, Okayama, Japan

H. Kumagai

Institute for Research on Earth Evolution (IFREE), Japan Agency for Marine-Earth Science and Technology (JAMSTEC), Yokosuka, Japan

K. Ikehata

Faculty of Life and Environmental Sciences, University of Tsukuba,

Tsukuba, Japan 
Keywords

BMS shallow drilling • Massive sulfide deposits • U-Th disequilibrium dating

\subsection{Introduction}

Studies dating of hydrothermal mineralization provide key information for understanding formation processes of seafloor massive sulfide deposits, since prolonged hydrothermal activity is undoubtedly required to accumulate metals needed to form an economic ore deposit. Application of radiometric dating technique to studies dating of hydrothermal mineralization has attempted since 1980s (e.g., Lalou and Brichet 1987). Many of pioneering studies, however, reported age data only for a limited numbers of samples collected from one or two hydrothermal fields, and the age data were simply attributed to be a sign for active and resting stages of episodic hydrothermal activity (e.g. Lalou et al. 1995). Recent improvements in analytical techniques have contributed to reduce both sample volume and analysis time, which enabled us to conduct a systematic study to discuss linkage between a series of chronological data and records of geologic events (e.g., You and Bickle 1998; Ditchburn et al. 2012). Jamieson et al. (2013) conducted a dating study of mineralized samples collected from inside slope and outside of the axial valley of the Juan de Fuca ridge. They revealed temporal and spatial history of hydrothermal activity, which appears to have been closely related to evolution of the axial valley. de Ronde et al. (2011) conducted a dating study of chimney samples divided into some parts and compared the age data with geochemical data. They revealed how episodic magmatic input into the system affects the accumulation of metals based on a relationship between fluctuating geochemical data along ages.

During the TAIGA project, we have developed application of two different techniques; ${ }^{230} \mathrm{Th} /{ }^{234} \mathrm{U}$ radioactive disequilibrium and electron spin resonance (ESR) to hydrothermal minerals (Takamasa et al. 2013, Kumagai et al. Chap. 5). The ${ }^{230} \mathrm{Th} /{ }^{234} \mathrm{U}$ radioactive disequilibrium technique is applied to sulfide minerals. When sulfide minerals precipitate from the hydrothermal fluid, $\mathrm{U}$ is usually incorporated into them but $\mathrm{Th}$ is completely absent. Once sulfide mineral precipitated, ${ }^{230} \mathrm{Th}$ accumulates due to radioactive decay of ${ }^{234} \mathrm{U}$, and ${ }^{230} \mathrm{Th} /{ }^{234} \mathrm{U}$ ratio gradually approaches to the radioactive equilibrium with time. From the half-lives of ${ }^{230} \mathrm{Th}$ and ${ }^{234} \mathrm{U}$, this technique is applicable to dating an age range from $10^{2}$ to $10^{5}$ years. The ESR dating is based on the idea that paramagnetic defects with unpaired electrons are created by natural radiation and accumulates with time since mineral precipitation. Okumura et al. (2010) first practically applied this technique to barite in samples collected from the seafloor, by determining signal intensities of the paramagnetic defects with $\mathrm{SO}_{3}{ }^{-}$radical. Toyoda et al. (2011) estimated an age range of application of the ESR dating for barite from $10^{2}$ to $10^{5}$ years based on estimation for stability of paramagnetic defects. This age range (from $10^{2}$ to $10^{5}$ years) cannot relate with a time series change which visual observation records, but would cover broad spectra of events related to hydrothermal activity such as formation of a massive sulfide deposit (Kumagai et al. Chap. 5). For longer time range, $>10^{4}$ years, ${ }^{39} \mathrm{Ar}-{ }^{40} \mathrm{Ar}$ dating technique is well known as an established technique for volcanic rock samples. Application of ${ }^{39} \mathrm{Ar}-{ }^{40} \mathrm{Ar}$ dating technique directly for hydrothermal minerals is difficult, mainly due to too much activation during irradiation for ${ }^{39} \mathrm{Ar}$ production. Recently, micro scale analysis combined with a laser step heating is often adopted to avoid influence of alteration processes, especially for volcanic rock samples collected from the seafloor. We have attempted this technique for dating some volcanic rocks during the TAIGA project.

We have conducted a systematic dating study of four hydrothermal sites in the Southern Mariana Trough. A range in geochemical compositions and mineralogical assemblages have been shown within hydrothermal sites located both on- and off-axis, along a single tectonic lineament (Seama et al. Chap. 17; Ikehata et al. Chap. 22). Results of the dating study could provide information for discussion on temporal and spatial history of hydrothermal activity in this area. Moreover, a series of ore samples from massive sulfide deposit was obtained by shallow drilling conducted in this area (Nakamura et al. Chap. 41), which provide a good opportunity to apply dating study to discuss the duration of deposit formation. For the majority of samples, ${ }^{230} \mathrm{Th} /{ }^{234} \mathrm{U}$ radioactive disequilibrium dating was applied to sulfide minerals because the collected samples are dominated by marcasite, pyrite and sphalerite. In addition, electron spin resonance (ESR) dating was applied to a few barite-rich samples, for cross comparison purpose. Other than these, a laser step heating ${ }^{39} \mathrm{Ar}-{ }^{40} \mathrm{Ar}$ method was applied to volcanic basement samples in order to constrain the upper age limit for hydrothermal activity in the area.

\subsection{Hydrothermal Activity in the Southern Mariana Trough at $13^{\circ} \mathrm{N}$}

Hydrothermal fields targeted in this study include a series of active hydrothermal sites located in the Southern Mariana Trough, at $13^{\circ} \mathrm{N}$ (Fig. 23.1). The geologic setting of this 
Fig. 23.1 Bathymetric maps of the Southern Mariana Trough, around $13^{\circ} \mathrm{N}$. Localities of the hydrothermal sites studied are given by the star symbols

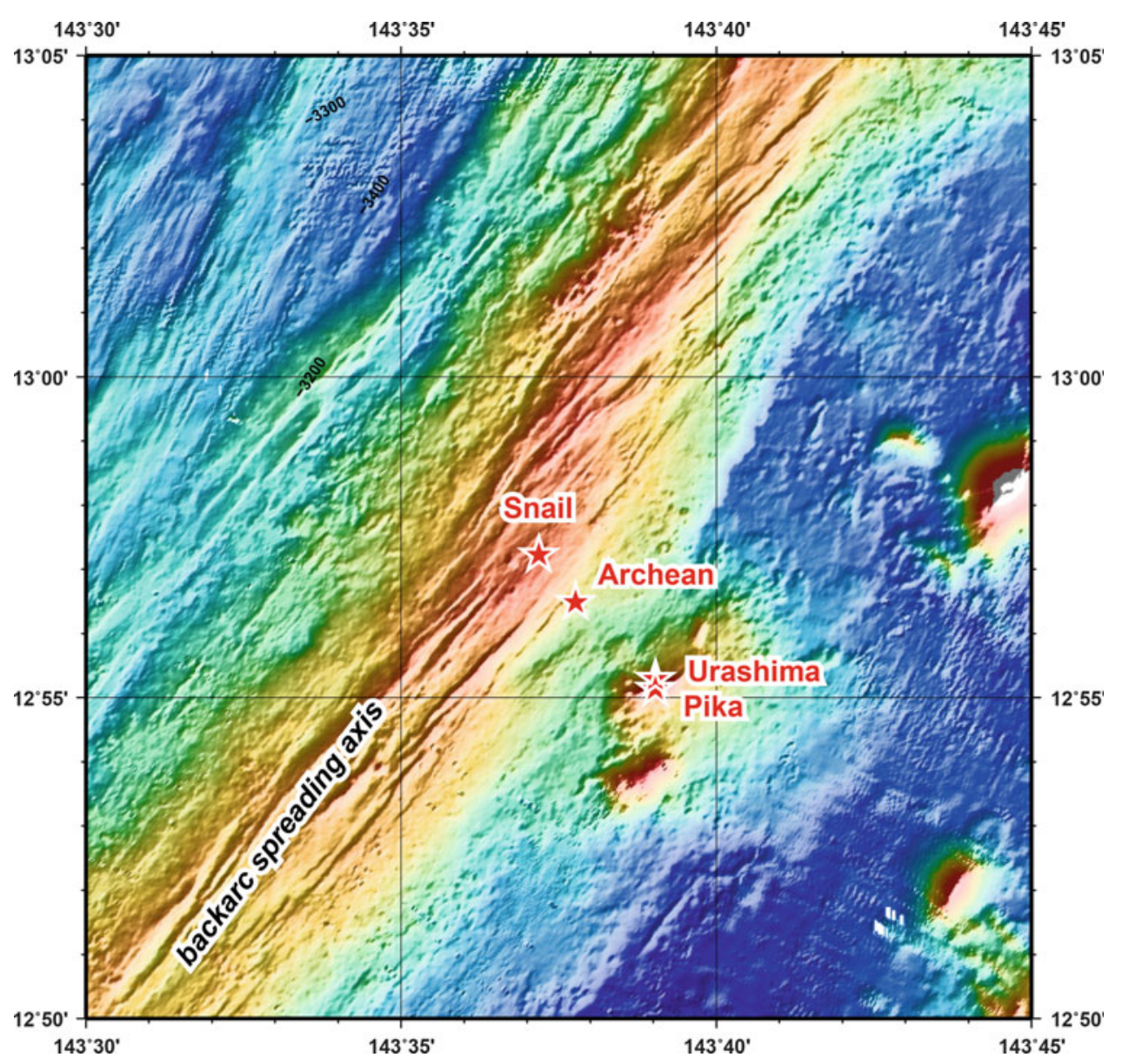

area is described in detail elsewhere in this volume (Seama et al. Chap. 17) and also in previous papers (Yoshikawa et al. 2012; Nakamura et al. 2013). The essential points are summarized below.

The Archaean site is located at the foot of an axial high, at water depths between $\sim 2,980$ and $3,030 \mathrm{~m}$. This site is located on a single conical shaped mound with a diameter of 250-300 m and a height above the seafloor of 50-100 m (Yoshikawa et al. 2012). Although the shape of the mound was attributed to an off-axis lava dome, its surface is dominantly covered by sulfidic ores, which are commonly hosted by breccia assemblages (Yoshikawa et al. 2012). Active and inactive chimneys have been observed in several places atop the mound. The highest measured temperature for the venting fluid is $343{ }^{\circ} \mathrm{C}$ (Toki et al. Chap. 45).

The Pika site is located at the top of an off-axis knoll, $4.9 \mathrm{~km}$ southeast of the spreading axis. This site covers an area about $100 \times 400 \mathrm{~m}$ on the seafloor. Slightly shifted from the active vent area, a breccia assemblage consisting of sulfide ore was commonly seen. Hydrothermal activity of the Pika site is represented by black smokers with the highest measured fluid temperature of $320{ }^{\circ} \mathrm{C}$ and areas of diffuse flow, as well as many inactive chimney structures and spires (Toki et al. Chap. 45).
The Urashima site, a recently discovered active field, is located at the northern slope of the same knoll as the Pika site, but about $500 \mathrm{~m}$ to the north (Nakamura et al. 2013). This site covers an area about $300 \times 300 \mathrm{~m}$. Hydrothermal activity is characterized by clusters of active and inactive chimneys that are $5 \mathrm{~m}$ tall, or more. The highest fluid temperature measured from an active vent was $280{ }^{\circ} \mathrm{C}$ (Nakamura et al. 2013).

The Snail hydrothermal site is located on the spreading axis, at water depth of $\sim 2,850 \mathrm{~m}$. This site is characterized by abundant volcanic mounds consisting of mainly pillow lavas that are cut by fissures (Yoshikawa et al. 2012). Venting of $100-150{ }^{\circ} \mathrm{C}$ transparent fluid associated with hydrothermal mounds was observed outcropping on the slope of $5 \mathrm{~m}$ tall volcanic mound.

\subsection{Material and Methods}

\subsubsection{Sample Collection}

Hydrothermal mineralized samples were obtained using the manned submersible SHINKAI 6500 during the YK10-11 cruise of the $R / V$ Yokosuka conducted in August 2010. These samples were collected from clusters of active or 
inactive chimneys, or from small mounds, using a manipulator on the submersible. Brecciated sulfide blocks that amassed on the slope as talus were collected by the submersible and formed part of this study. Samples recovered by the submersible are summarized in Table 23.1.

Other samples were recovered by drilling using a BMS (Benthic Multi-coring System) during the TAIGA10 cruise of the R/V Hakurei-Maru No.2 conducted in June 2010. Detailed information of operations during this cruise is reported in other chapter (Nakamura et al. Chap. 41). Core samples were obtained from four drilled sites; BMS02, BMS03 and BMS07 from the Archean Site, and BMS09 from the Pika Site. These cores provided a continuous record of sulfide mineralization at these sites and highlight the success of drilling into massive sulfide deposits. The samples obtained by BMS drilling are given in Table 23.2.

Other than mineralized samples, some volcanic rock samples were also provided for a ${ }^{39} \mathrm{Ar}-{ }^{40} \mathrm{Ar}$ dating study. A list of these samples is given as Table 23.3.

\subsubsection{Mineralogical Analysis}

The samples collected by the submersible were cut into slabs of $\sim 5 \times 5 \mathrm{~cm}$ in size, whereas the core samples recovered by the BMS drilling (core diameter is $4.9 \mathrm{~cm}$ ) were cut into sections a few $\mathrm{cm}$ in thickness. In parallel with dating analysis, mineralogy of the samples was determined by X-ray diffraction (XRD) after powdered. Texture of mineral was observed and determined using a thin section by microscope and Electron Probe Micro Analyzer (EPMA), which was conducted using JXA-8530F (JEOL) at $20 \mathrm{kV}$ of accelerated voltage.

\subsubsection{Dating Analysis}

Analytical protocol for ${ }^{230} \mathrm{Th} /{ }^{234} \mathrm{U}$ radioactive disequilibrium dating followed our previous study (Takamasa et al. 2013). Aliquots of $\sim 2 \mathrm{~g}$ of crushed samples were treated in $13 \mathrm{M}$ nitric acid heated at $85{ }^{\circ} \mathrm{C}$ for 3 days to dissolve sulfide minerals and to separate them from insoluble minerals (mainly barite). After purification by column separation procedures using AG1-X8 and U/TEVA resins sequentially, $\mathrm{U}$ and $\mathrm{Th}$ isotope measurements were conducted using a multi-collector ICP mass spectrometer (MC-ICP-MS).

Analytical procedures for ESR dating followed our previous studies (Okumura et al. 2010; Toyoda et al. 2011). Aliquots of crushed powder were prepared separately from the same sample as used in the ${ }^{230} \mathrm{Th} /{ }^{234} \mathrm{U}$ dating. Barite was separated from sulfide minerals by leaching with $12 \mathrm{M}$ hydrochloric acid and $13 \mathrm{M}$ nitric acid, sequentially. After rinsing, the residue was collected by filtration and prepared
Table 23.1 Samples collected during submersible dive expeditions

\begin{tabular}{|c|c|c|c|c|c|}
\hline \multirow[b]{2}{*}{ Sample ID } & \multirow[b]{2}{*}{$\begin{array}{l}\text { Sampling } \\
\text { date }\end{array}$} & \multicolumn{2}{|c|}{ Sampling position } & \multirow{2}{*}{$\begin{array}{l}\text { Water } \\
\text { Depth } \\
(\mathrm{m})\end{array}$} & \multirow[b]{2}{*}{ Description } \\
\hline & & $\begin{array}{l}\text { Latitude } \\
\text { (N) }\end{array}$ & $\begin{array}{l}\text { Longitude } \\
\text { (E) }\end{array}$ & & \\
\hline \multicolumn{6}{|c|}{ Archaean site } \\
\hline $\begin{array}{l}\text { 6K903 } \\
\text { R07-2 }\end{array}$ & $7 / 29 / 2005$ & $\begin{array}{l}12^{\circ} \\
56.3625^{\prime}\end{array}$ & $\begin{array}{l}143^{\circ} \\
37.9000^{\prime}\end{array}$ & 2,974 & Sulfide crust \\
\hline $\begin{array}{l}\text { 6K1221 } \\
\text { R05-1 }\end{array}$ & $9 / 5 / 2010$ & $\begin{array}{l}12^{\circ} \\
56.3255^{\prime}\end{array}$ & $\begin{array}{l}143^{\circ} \\
37.8875^{\prime}\end{array}$ & 3,014 & $\begin{array}{l}\text { Inactive } \\
\text { chimney }\end{array}$ \\
\hline $\begin{array}{l}\text { 6K1221 } \\
\text { R07-1 }\end{array}$ & $9 / 5 / 2010$ & $\begin{array}{l}12^{\circ} \\
56.3627^{\prime}\end{array}$ & $\begin{array}{l}143^{\circ} \\
37.9022^{\prime}\end{array}$ & 2,970 & $\begin{array}{l}\text { Active } \\
\text { chimney }\end{array}$ \\
\hline $\begin{array}{l}\text { 6K1223 } \\
\text { R03-1 }\end{array}$ & $9 / 7 / 2010$ & $\begin{array}{l}12^{\circ} \\
56.3795^{\prime}\end{array}$ & $\begin{array}{l}143^{\circ} \\
37.9206^{\prime}\end{array}$ & 3,000 & $\begin{array}{l}\text { Active } \\
\text { chimney }\end{array}$ \\
\hline $\begin{array}{l}\text { 6K1224 } \\
\text { R02 }\end{array}$ & 9/9/2010 & $\begin{array}{l}12 \\
56.3643^{\prime}\end{array}$ & $\begin{array}{l}143^{\circ} \\
37.8954^{\prime}\end{array}$ & 2,972 & $\begin{array}{l}\text { Active } \\
\text { chimney }\end{array}$ \\
\hline \multicolumn{6}{|l|}{ Pika site } \\
\hline $\begin{array}{l}\text { 6K1226 } \\
\text { R02 }\end{array}$ & $9 / 12 / 2010$ & $\begin{array}{l}12^{\circ} \\
55.1628^{\prime}\end{array}$ & $\begin{array}{l}143^{\circ} \\
38.9482^{\prime}\end{array}$ & 2,782 & $\begin{array}{l}\text { sulfide } \\
\text { breccia }\end{array}$ \\
\hline \multicolumn{6}{|c|}{ Urashima site } \\
\hline $\begin{array}{l}\text { 6K1222 } \\
\text { R06-1 }\end{array}$ & $9 / 6 / 2010$ & $\begin{array}{l}12^{\circ} \\
55.2839^{\prime}\end{array}$ & $\begin{array}{l}143^{\circ} \\
38.8726^{\prime}\end{array}$ & 2,919 & $\begin{array}{l}\text { Active } \\
\text { chimney }\end{array}$ \\
\hline $\begin{array}{l}\text { 6K1222 } \\
\text { R07-1 }\end{array}$ & $9 / 6 / 2010$ & $\begin{array}{l}12^{\circ} \\
55.2667^{\prime}\end{array}$ & $\begin{array}{l}143^{\circ} \\
38.8686^{\prime}\end{array}$ & 2,905 & $\begin{array}{l}\text { Inactive } \\
\text { chimney }\end{array}$ \\
\hline $\begin{array}{l}\text { 6K1226 } \\
\text { R03 }\end{array}$ & $9 / 12 / 2010$ & $\begin{array}{l}12^{\circ} \\
55.2969^{\prime}\end{array}$ & $\begin{array}{l}143^{\circ} \\
38.8756^{\prime}\end{array}$ & 2,926 & $\begin{array}{l}\text { Active } \\
\text { chimney }\end{array}$ \\
\hline \multicolumn{6}{|l|}{ Snail site } \\
\hline $\begin{array}{l}\text { 6K1227 } \\
\text { R01 }\end{array}$ & $9 / 13 / 2010$ & $\begin{array}{l}12^{\circ} \\
57.1978^{\prime}\end{array}$ & $\begin{array}{l}143^{\circ} \\
37.1756^{\prime}\end{array}$ & 2,848 & $\begin{array}{l}\text { Sulfide } \\
\text { breccia }\end{array}$ \\
\hline $\begin{array}{l}\text { 6K1228 } \\
\text { R03 }\end{array}$ & $9 / 14 / 2010$ & $\begin{array}{l}12^{\circ} \\
57.1902^{\prime}\end{array}$ & $\begin{array}{l}143^{\circ} \\
37.1487^{\prime}\end{array}$ & 2,847 & $\begin{array}{l}\text { Sulfide } \\
\text { breccia }\end{array}$ \\
\hline
\end{tabular}

${ }^{\mathrm{a}}$ Dating results presented in a previous study (Takamasa et al. 2013) are discussed together

for measurements of radiation. Signal intensity due to paramagnetic defect of the $\mathrm{SO}_{3}{ }^{-}$radical was measured using an ESR spectrometer, after the samples were irradiated using a ${ }^{60} \mathrm{Co}$ gamma ray source at the Takasaki Advanced Radiation Research Institute of the Japan Atomic Energy Agency. Concentration of ${ }^{226} \mathrm{Ra}$ was determined separately by gamma-ray spectrometry.

Analytical procedures for ${ }^{39} \mathrm{Ar}-{ }^{40} \mathrm{Ar}$ method with a laser step heating are described below. At a hand specimen scale, very fresh portions of the rock samples were crushed and sieved (\#20-40 mesh). After confirmed no phenocrysts included, a few fragments ( $\sim 1 \mathrm{~mm}$ in diameter) of groundmass were handpicked, and irradiated in the core of the Kyoto University Research Reactor. In this study, only pyroxene was identified as phenocryst in sample BMS03$02 \mathrm{C}$, which was analyzed separately as BMS03-02C Px1 for comparison. Once the radioactivity had decreased, the irradiated samples were placed into a vacuum-sealed sample chamber and heated by a $5 \mathrm{~W}$ argon ion continuous laser with a defocused beam for stepwise heating. Temperatures were measured to a precision of $5 \mathrm{~K}$ utilizing monitoring and feedback controls through an infrared thermometer 
Table 23.2 Samples collected by BMS drilling

\begin{tabular}{|c|c|c|c|c|c|}
\hline \multirow[b]{2}{*}{ Sample ID } & \multirow[b]{2}{*}{ Sampling date } & \multicolumn{2}{|c|}{ Sampling position } & \multirow{2}{*}{$\frac{\text { Water }}{\text { Depth }(\mathrm{m})}$} & \multirow{2}{*}{$\begin{array}{l}\text { Sample depth below } \\
\text { the seafloor (cmbsf) }\end{array}$} \\
\hline & & Latitude (N) & Longitude (E) & & \\
\hline \multicolumn{6}{|l|}{ Archaean site } \\
\hline BMS02 2 19-30 & $6 / 16 / 2010$ & $12^{\circ} 56.3696^{\prime}$ & $143^{\circ} 37.9599^{\prime}$ & 3,073 & $26-37$ \\
\hline BMS02 2 53-57 & ditto & ditto & ditto & ditto & $60-64$ \\
\hline BMS02 2 75-80 & ditto & ditto & ditto & ditto & $82-87$ \\
\hline BMS03 2B 08-42 & $6 / 16 / 2010$ & $12^{\circ} 56.3627^{\prime}$ & $143^{\circ} 37.9036^{\prime}$ & 3,024 & $133-167$ \\
\hline BMS03 2B 42-65 & ditto & ditto & ditto & ditto & $167-190$ \\
\hline BMS03 2C 03-20 & ditto & ditto & ditto & ditto & $220-237$ \\
\hline BMS03 2C 40-56 & ditto & ditto & ditto & ditto & $257-273$ \\
\hline BMS03 2C 58-80 (a) & ditto & ditto & ditto & ditto & 275 \\
\hline BMS03 2C 58-80 (b) & ditto & ditto & ditto & ditto & 284 \\
\hline BSM03 2C 58-80 (c) & ditto & ditto & ditto & ditto & 297 \\
\hline BMS07 1 61-71 & $6 / 20 / 2010$ & $12^{\circ} 56.3783^{\prime}$ & $143^{\circ} 37.9187^{\prime}$ & 3,008 & $17-27$ \\
\hline BMS07 2B 12-20 & ditto & ditto & ditto & ditto & $164-172$ \\
\hline BMS07 2B 27-40 & ditto & ditto & ditto & ditto & $179-192$ \\
\hline BMS07 2B 44-55 (a) & ditto & ditto & ditto & ditto & 196 \\
\hline BMS07 2B 44-55 (b) & ditto & ditto & ditto & ditto & 207 \\
\hline \multicolumn{6}{|l|}{ Pika site } \\
\hline BMS09 2B 23-31 & $6 / 21 / 2010$ & $12^{\circ} 55.1368^{\prime}$ & $143^{\circ} 38.9333^{\prime}$ & 2,804 & $165-173$ \\
\hline BMS09 2B 45-58 (a) & ditto & ditto & ditto & ditto & 184 \\
\hline BMS09 2B 45-58 (b) & ditto & ditto & ditto & ditto & 200 \\
\hline BMS09 2B 65-71 & ditto & ditto & ditto & ditto & $207-213$ \\
\hline
\end{tabular}

Table 23.3 Volcanic rock samples

\begin{tabular}{lllll}
\hline \multirow{2}{*}{$\begin{array}{l}\text { Sample ID } \\
\text { date }\end{array}$} & \multicolumn{2}{l}{ Sampling position } & Water \\
\cline { 3 - 5 } & Latitude (N) & Longitude (E) & Depth $(\mathrm{m})$ \\
\hline $\begin{array}{lllll}\text { Archaean site } \\
\text { 6K1221 R02 }\end{array}$ & $9 / 5 / 2010$ & $12^{\circ} 56.2201^{\prime}$ & $143^{\circ} 37.8993^{\prime}$ & 3,082 \\
\hline $\begin{array}{l}\text { BMS6C } \\
\text { 62-75 }\end{array}$ & $6 / 19 / 2010$ & $12^{\circ} 56.3358^{\prime}$ & $143^{\circ} 37.0094^{\prime}$ & 3,108 \\
\hline $\begin{array}{l}\text { BMS6D } \\
\text { 44-45 }\end{array}$ & $6 / 19 / 2010$ & $12^{\circ} 56.3222^{\prime}$ & $143^{\circ} 38.0042^{\prime}$ & 3,115 \\
\hline Urashima site & & & & \\
\hline 6K1226 R01 & $9 / 6 / 2010$ & $12^{\circ} 55.2962^{\prime}$ & $143^{\circ} 39.0282^{\prime}$ & 2,917 \\
\hline
\end{tabular}

(Hyodo 2008). The argon isotopes were then measured on a custom made mass spectrometer with a mass resolution of approximately 400 at the Research Institute of Natural Sciences, from which the Ar isotope ratio, ages, and correction factors were calculated. Typical blanks for argon isotopes in the extraction system were $6.2 \times 10^{-14}, 8.7 \times 10^{-14}$, $3.8 \times 10^{-14}, 5.2 \times 10^{-14}$, and $2.6 \times 10^{-12} \mathrm{~cm}^{3}$ for ${ }^{36} \mathrm{Ar}$, ${ }^{37} \mathrm{Ar},{ }^{38} \mathrm{Ar},{ }^{39} \mathrm{Ar}$, and ${ }^{40} \mathrm{Ar}$, respectively. All errors shown are at the $2 \sigma$ level.

\subsection{Results}

Pictures of representative mineralized samples are shown in Fig. 23.2, together with back scatter electron (BSE) images of the polished section prepared from the same samples.
Marcasite, pyrite and sphalerite were recognized as dominant sulfide minerals in most of the collected samples in this study. Barite was identified in several samples as a minor amount, and chalcopyrite was identified mainly in chimney samples. These occurrences of sulfide and sulfate minerals are consistent with results of mineralogical study for the same hydrothermal sites reported in other Chapter (Ikehata et al. Chap. 22). As remarkable features in mineral texture, significant void spaces are noticeable in the chimney samples (Fig. 23.2a, b). On the other hand, less but still some void spaces are recognized in the ore samples recovered by the BMS drilling (Fig. 23.2c, d), suggesting mineralization have occurred repeatedly filling up the void to form a massive sulfide deposit.

Results of ${ }^{230} \mathrm{Th} /{ }^{234} \mathrm{U}$ radioactive disequilibrium dating are summarized in Table 23.4. Concentrations of $\mathrm{U}$ and $\mathrm{Th}$ are calculated relative to the total weight of the sample (including other minerals such as barite). Consequently, $\mathrm{U}$ and Th abundance in the analyzed sulfide fraction would likely be higher than the reported values. ${ }^{230} \mathrm{Th} /{ }^{234} \mathrm{U}$ disequilibrium ages were calculated using the following equation from the radioactivity ratio,

$$
\mathrm{t}=-\frac{1}{\lambda^{230} T h} \ln \left(1-\frac{{ }^{230} T h}{{ }^{234} U}\right)
$$

where $\lambda^{230} \mathrm{Th}$ is the decay constant of ${ }^{230} \mathrm{Th}\left(\lambda^{230} \mathrm{Th}\right.$ $=9.1577 \times 10^{-6}$ year $\left.^{-1}\right)$. This equation assumes the absence of ${ }^{230} \mathrm{Th}$ at the time of sulfide mineral precipitation. 


\section{a 6K1226R03}

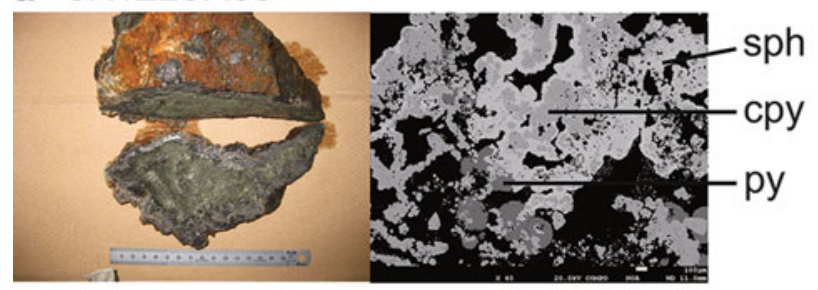

b $6 K 1228 R 03$

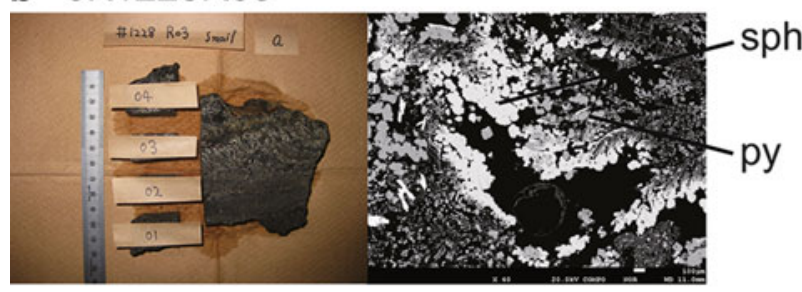

c BMS07-02B 44-55

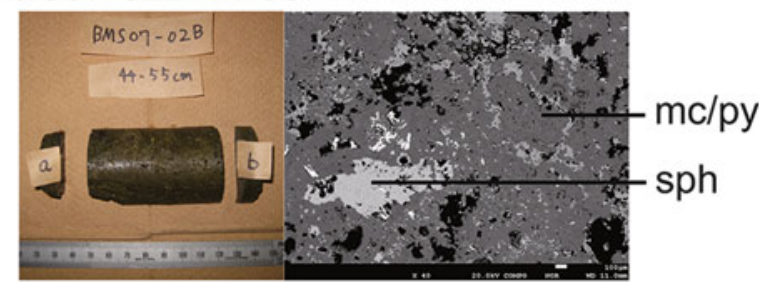

d BMS09-02B 45-58

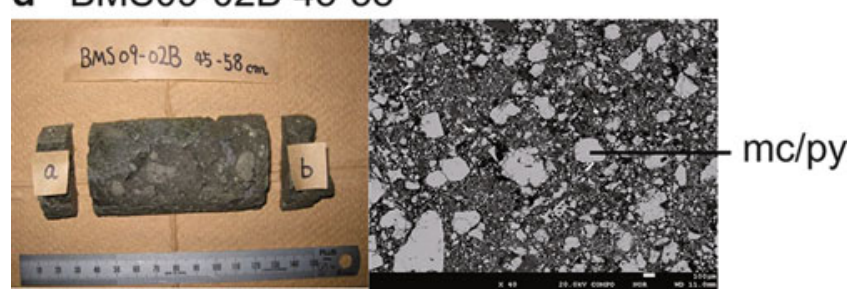

Fig. 23.2 Pictures of selected mineralized samples (left) and back scatter electron (BSE) images of the polished section from the same samples (right); (a) sample 6K1226R03 from the Urashima site, (b) sample 6K1228R03 from the Snail site, (c) sample BMS07-02B 44-55 from the Archaean site, and (d) sample BMS09-02B 45-58 from the Pika site. Abbreviations for minerals are sph sphalerite, cpy chalcopyrite, $p y$ pyrite, $m c$ marcasite

As in an earlier study (Takamasa et al. 2013), we also corrected ${ }^{230} \mathrm{Th} /{ }^{234} \mathrm{U}$ ages for possible contribution of silicate minerals derived from sediment, as this would cause a shift of the initial ${ }^{230} \mathrm{Th} /{ }^{234} \mathrm{U}$ ratio away from zero. Corrected ${ }^{230} \mathrm{Th} /{ }^{234} \mathrm{U}$ values and corrected ages are shown in Table 23.4. Uncertainties of the calculated age are estimated as $3 \%$, based on analytical uncertainties of the ${ }^{230} \mathrm{Th} /{ }^{232} \mathrm{Th}$ and ${ }^{234} \mathrm{U} /{ }^{232} \mathrm{Th}$ values. Where there was insufficient $\mathrm{Th}$ in a sample to allow for a reliable analysis, we abandoned plans to date that sample. Based on preliminary tests, this method can be applied to samples with ages as young as $\sim 100$ years. On the other hand, substantial depletion in the abundance of $U$ is likely to be attributed to sulfide having suffered from $U$ loss due to hydrothermal alteration.
In such a scenario, the apparent age should be much older. Corrected U-Th ages are $<100$ to 3,520 years old for the samples collected from the Archaean site, from 300 to 8,950 years old for the Pika site, from 250 to 9,130 years old for the Urashima site, and 2,740 and 7,190 years old for the Snail site.

Results of ESR dating are presented in Supplementary Data (Suppl. 23_S1). Accumulated natural radiation dose is estimated by the additive dose method. At first, dose response was examined for each sample by measuring ESR signal intensity due to the paramagnetic defects, as a function of additive dose by artificial gamma ray irradiation. Then, the dose response was fitted and extrapolated to the zero ordinate to determine an originally had accumulated dose for the sample, which is given as an equivalent dose in the table. To deduce age, the equivalent dose is subsequently divided by dose rate. Preliminary tests by Okumura et al. (2010) found that $\mathrm{Ra}$ is the only important source of radiation located in barite crystals and that the dose rate is estimated from ${ }^{226} \mathrm{Ra}$ content in the barite. The dose rates of alpha, beta and gamma rays $\left(D_{\alpha}, D_{\beta}\right.$, and $\left.D \gamma\right)$ were calculated according to the method adopted by Okumura et al. (2010) and given in the table. Age uncertainties are calculated by standard error propagation. Obtained ESR ages are 1,110 years old for one sample from the Archaean site, from 180 to 4,580 years old for the Pika site, and 110 and 390 years old for the Snail site.

Results of ${ }^{39} \mathrm{Ar}-{ }^{40} \mathrm{Ar}$ dating are presented in Supplementary Data (Suppl. 23_S2), and ${ }^{39} \mathrm{Ar}-{ }^{40} \mathrm{Ar}$ age spectra on plots of cumulative ${ }^{39} \mathrm{Ar}$ versus apparent ages were shown in Supplementary file (Suppl. 23_S3). In this study, no ${ }^{39} \mathrm{Ar}-{ }^{40} \mathrm{Ar}$ age spectra formed "plateau". A plateau is a sequence formed by more than two contiguous temperature steps containing more than $50 \%$ of the total released ${ }^{39} \mathrm{Ar}$, which provides one criteria for a reliable ${ }^{39} \mathrm{Ar}-{ }^{40} \mathrm{Ar}$ age from the sample (e.g., Baksi 1999). In general, only one thirds or less of submarine lava samples show clear plateau, partially due to their high $\mathrm{Ca}$ but low $\mathrm{K}$ signature (e.g. Wanke et al. 2012). In many cases, irradiation produced nuclei from $\mathrm{Ca}$ largely contribute into ${ }^{36} \mathrm{Ar}$, which results in a negative age due to over-corrections (McDougall and Harrison 1999). In this study, rather disturbed spectra were obtained, meaning difficult to deduce fully reliable ${ }^{39} \mathrm{Ar}-{ }^{40} \mathrm{Ar}$ age. Samples "6K1221R02MT1" and "6K1221R02MT3" collected from near the Archaean site showed fair release of ${ }^{36} \mathrm{Ar}$ in high temperature fractions; these two samples gave 16-0 Ma as their total ages and interpreted ages are calculated as 6-0 Ma after the corrections of possible irradiation produced ${ }^{36} \mathrm{Ar}$. We cannot exclude possibility that these interpreted ${ }^{39} \mathrm{Ar}-{ }^{40} \mathrm{Ar}$ ages may be rejuvenated by later alteration, however, it seems to be consistent with 1-2 Ma of the seafloor age estimated from spreading rate in the area. 
Table 23.4 Results of radioactive disequilibrium dating of sulfide mineralization

\begin{tabular}{|c|c|c|c|c|c|c|c|c|c|}
\hline Sample ID & Fraction & $\begin{array}{l}\mathrm{U} \\
(\mathrm{ppb})^{\mathrm{a}}\end{array}$ & $\begin{array}{l}\text { Th } \\
(\mathrm{ppb})\end{array}$ & ${ }^{234}{ }_{\mathrm{U} /}{ }^{238} \mathrm{U}$ & $230_{\mathrm{Th}} /^{232} \mathrm{Th}$ & ${ }^{230} \mathrm{Th} /{ }^{234} \mathrm{U}$ & $\begin{array}{l}\text { Age } \\
\text { (years) }\end{array}$ & $\begin{array}{c}230_{\mathrm{Th}} / \\
234 \mathrm{U} \\
\mathrm{b} \\
\text { corr. }\end{array}$ & $\begin{array}{l}\text { Age (years) } \\
\text { corr. }\end{array}$ \\
\hline \multicolumn{10}{|l|}{ Archaean site } \\
\hline BMS02 219-30 & & $9.34 \mathrm{E}+02$ & 4.67E-02 & $6.35 \mathrm{E}-05$ & $5.63 \mathrm{E}-03$ & $1.48 \mathrm{E}-02$ & $1.63 \mathrm{E}+03$ & $1.48 \mathrm{E}-02$ & 1,630 \\
\hline BMS02 253-57 & & $8.13 \mathrm{E}+02$ & $6.43 \mathrm{E}-02$ & $6.34 \mathrm{E}-05$ & u. d. & - & - & - & - \\
\hline \multirow[t]{2}{*}{ BMS02 275-80 } & $\mathrm{nm}$ & $2.69 \mathrm{E}+03$ & $9.49 \mathrm{E}-02$ & $6.25 \mathrm{E}-05$ & $7.82 \mathrm{E}-03$ & $1.48 \mathrm{E}-02$ & $1.63 \mathrm{E}+03$ & $1.48 \mathrm{E}-02$ & 1,630 \\
\hline & mag & $3.04 \mathrm{E}+03$ & 5.33E-02 & $6.10 \mathrm{E}-05$ & $1.31 \mathrm{E}-02$ & $1.24 \mathrm{E}-02$ & $1.37 \mathrm{E}+03$ & $1.24 \mathrm{E}-02$ & 1,370 \\
\hline BMS03 2B 08-42 & & $6.11 \mathrm{E}+01$ & $4.16 \mathrm{E}-03$ & $6.38 \mathrm{E}-05$ & u. d. & - & - & - & - \\
\hline BMS03 2B 42-65 (a) & & $1.87 \mathrm{E}+02$ & $1.66 \mathrm{E}-02$ & $6.32 \mathrm{E}-05$ & $2.34 \mathrm{E}-03$ & $1.10 \mathrm{E}-02$ & $1.21 \mathrm{E}+03$ & $1.10 \mathrm{E}-02$ & 1,210 \\
\hline BMS03 2B 42-65 (b) & & $3.03 E+02$ & $5.74 \mathrm{E}-02$ & $6.33 \mathrm{E}-05$ & $2.98 \mathrm{E}-04$ & $2.99 \mathrm{E}-03$ & $3.27 \mathrm{E}+02$ & $2.94 \mathrm{E}-03$ & 320 \\
\hline BMS03 2C 03-20 (a) & & $2.25 \mathrm{E}+02$ & $2.93 \mathrm{E}-02$ & $6.32 \mathrm{E}-05$ & $3.07 \mathrm{E}-03$ & $2.12 \mathrm{E}-02$ & $2.33 \mathrm{E}+03$ & $2.11 \mathrm{E}-02$ & 2,330 \\
\hline BMS03 2C 40-56 (a) & & $2.16 \mathrm{E}+03$ & $1.18 \mathrm{E}-01$ & $6.31 \mathrm{E}-05$ & $3.87 \mathrm{E}-03$ & $1.13 \mathrm{E}-02$ & $1.24 \mathrm{E}+03$ & $1.13 \mathrm{E}-02$ & 1,240 \\
\hline \multirow[t]{3}{*}{ BMS03 2C 58-80 (a) } & $\mathrm{nm} 100$ & $6.27 \mathrm{E}+02$ & $6.91 \mathrm{E}-01$ & 4.69E-05 & $3.88 \mathrm{E}-04$ & $3.05 \mathrm{E}-02$ & $3.38 \mathrm{E}+03$ & $3.02 \mathrm{E}-02$ & 3,350 \\
\hline & $\operatorname{mg} 100$ & $7.60 \mathrm{E}+02$ & $8.82 \mathrm{E}-02$ & $6.19 \mathrm{E}-05$ & $4.09 \mathrm{E}-03$ & $2.57 \mathrm{E}-02$ & $2.84 \mathrm{E}+03$ & $2.56 \mathrm{E}-02$ & 2,840 \\
\hline & $\mathrm{nm} 250$ & $6.12 \mathrm{E}+02$ & 4.73E-02 & $4.78 \mathrm{E}-05$ & $4.74 \mathrm{E}-03$ & $2.56 \mathrm{E}-02$ & $2.84 \mathrm{E}+03$ & $2.56 \mathrm{E}-02$ & 2,830 \\
\hline \multirow[t]{2}{*}{ BMS03 2C 58-80 (b) } & $\mathrm{nm} 250$ & $4.80 \mathrm{E}+02$ & $4.55 \mathrm{E}-02$ & $5.83 \mathrm{E}-05$ & $4.34 \mathrm{E}-03$ & $2.18 \mathrm{E}-02$ & $2.41 \mathrm{E}+03$ & $2.18 \mathrm{E}-02$ & 2,400 \\
\hline & $\operatorname{mg} 250$ & $3.90 \mathrm{E}+02$ & $8.06 \mathrm{E}-02$ & $6.20 \mathrm{E}-05$ & $2.31 \mathrm{E}-03$ & $2.56 \mathrm{E}-02$ & $2.83 \mathrm{E}+03$ & $2.55 \mathrm{E}-02$ & 2,820 \\
\hline \multirow[t]{2}{*}{ BSM03 2C 58-80 (c) } & $\mathrm{nm} 100$ & $2.06 \mathrm{E}+02$ & $7.06 \mathrm{E}-02$ & $6.24 \mathrm{E}-05$ & $1.36 \mathrm{E}-03$ & $2.46 \mathrm{E}-02$ & $2.72 \mathrm{E}+03$ & $2.46 \mathrm{E}-02$ & 2,720 \\
\hline & $\mathrm{nm} 250$ & $2.13 \mathrm{E}+02$ & $2.77 \mathrm{E}-01$ & $6.24 \mathrm{E}-05$ & $3.70 \mathrm{E}-04$ & $2.55 \mathrm{E}-02$ & $2.82 \mathrm{E}+03$ & $2.52 \mathrm{E}-02$ & 2,790 \\
\hline BMS07 1 61-71 (a) & & $3.00 \mathrm{E}+03$ & $1.15 \mathrm{E}-01$ & $5.78 \mathrm{E}-05$ & 2.72E-04 & $6.05 \mathrm{E}-04$ & $6.61 \mathrm{E}+01$ & $5.64 \mathrm{E}-04$ & 61 \\
\hline BMS07 $161-71$ (b) & & $1.61 \mathrm{E}+03$ & $1.56 \mathrm{E}-01$ & $5.93 \mathrm{E}-05$ & $3.05 \mathrm{E}-05$ & $1.67 \mathrm{E}-04$ & $1.82 \mathrm{E}+01$ & $1.43 \mathrm{E}-04$ & 15 \\
\hline BMS07 2B 12-20 & & $4.95 \mathrm{E}+02$ & $1.03 \mathrm{E}-01$ & $6.38 \mathrm{E}-05$ & u. d. & - & - & - & - \\
\hline BMS07 2B 27-40 & & $8.59 \mathrm{E}+03$ & $2.04 \mathrm{E}-02$ & $6.31 \mathrm{E}-05$ & $8.31 \mathrm{E}-02$ & $1.05 \mathrm{E}-02$ & $1.15 \mathrm{E}+03$ & $1.05 \mathrm{E}-02$ & 1,150 \\
\hline \multirow[t]{2}{*}{ BMS07 2B 44-55 (b) } & run 1 & $5.65 \mathrm{E}+03$ & $2.27 \mathrm{E}-02$ & $6.32 \mathrm{E}-05$ & $5.16 \mathrm{E}-02$ & $1.10 \mathrm{E}-02$ & $1.20 \mathrm{E}+03$ & $1.10 \mathrm{E}-02$ & 1,200 \\
\hline & run 2 & $6.31 \mathrm{E}+03$ & $3.51 \mathrm{E}-02$ & $6.33 \mathrm{E}-05$ & $3.80 \mathrm{E}-02$ & $1.12 \mathrm{E}-02$ & $1.23 \mathrm{E}+03$ & $1.12 \mathrm{E}-02$ & 1,230 \\
\hline \multirow[t]{3}{*}{ 6K1221 R05-1 } & $\operatorname{mg} 250$ & $5.98 \mathrm{E}+02$ & $1.55 \mathrm{E}-01$ & $6.22 \mathrm{E}-05$ & $2.28 \mathrm{E}-03$ & $3.17 \mathrm{E}-02$ & $3.52 \mathrm{E}+03$ & $3.17 \mathrm{E}-02$ & 3,520 \\
\hline & $\operatorname{mg} 100$ & $3.57 \mathrm{E}+02$ & $2.50 \mathrm{E}-01$ & $5.98 \mathrm{E}-05$ & $6.24 \mathrm{E}-04$ & $2.45 \mathrm{E}-02$ & $2.71 \mathrm{E}+03$ & $2.43 \mathrm{E}-02$ & 2,690 \\
\hline & $\mathrm{nm} 100$ & $7.95 \mathrm{E}+01$ & 4.59E-02 & $5.74 \mathrm{E}-05$ & $3.04 \mathrm{E}-04$ & $1.02 \mathrm{E}-02$ & $1.12 \mathrm{E}+03$ & $1.01 \mathrm{E}-02$ & 1,110 \\
\hline 6K1221 R07-1 & $\mathrm{nm} 250$ & $1.62 \mathrm{E}+02$ & $1.17 \mathrm{E}-01$ & $6.18 \mathrm{E}-05$ & $5.41 \mathrm{E}-04$ & $2.11 \mathrm{E}-02$ & $2.33 \mathrm{E}+03$ & $2.10 \mathrm{E}-02$ & 2,320 \\
\hline \multirow[t]{2}{*}{ 6K1223 R03-1 } & $\operatorname{mg} 250$ & $2.64 \mathrm{E}+02$ & 4.03E-02 & $5.04 \mathrm{E}-05$ & $8.06 \mathrm{E}-04$ & $8.18 \mathrm{E}-03$ & $8.96 \mathrm{E}+02$ & $8.13 \mathrm{E}-03$ & 890 \\
\hline & $\operatorname{mg} 100$ & $2.54 \mathrm{E}+02$ & 4.94E-02 & $5.75 \mathrm{E}-05$ & $4.86 \mathrm{E}-04$ & $5.50 \mathrm{E}-03$ & $6.02 \mathrm{E}+02$ & $5.45 \mathrm{E}-03$ & 600 \\
\hline \multirow[t]{2}{*}{ 6K1224 R02 (a) } & run 1 & $2.71 \mathrm{E}+03$ & $7.01 \mathrm{E}-02$ & $6.27 \mathrm{E}-05$ & $3.02 \mathrm{E}-03$ & $4.16 \mathrm{E}-03$ & $4.56 \mathrm{E}+02$ & $4.16 \mathrm{E}-03$ & 460 \\
\hline & run 2 & $1.74 \mathrm{E}+03$ & $1.50 \mathrm{E}-01$ & $6.28 \mathrm{E}-05$ & $1.86 \mathrm{E}-03$ & $8.58 \mathrm{E}-03$ & $9.41 \mathrm{E}+02$ & $8.56 \mathrm{E}-03$ & 940 \\
\hline \multicolumn{10}{|l|}{ Pika site } \\
\hline \multirow[t]{2}{*}{ BMS09 2B 23-31 } & run 1 & $8.74 \mathrm{E}+02$ & $3.73 \mathrm{E}-02$ & $6.30 \mathrm{E}-05$ & $1.21 \mathrm{E}-03$ & $2.74 \mathrm{E}-03$ & $3.00 \mathrm{E}+02$ & $2.73 \mathrm{E}-03$ & 300 \\
\hline & run 2 & $3.11 \mathrm{E}+02$ & $3.43 \mathrm{E}-02$ & $6.29 \mathrm{E}-05$ & $4.59 \mathrm{E}-03$ & $2.69 \mathrm{E}-02$ & $2.97 \mathrm{E}+03$ & $2.68 \mathrm{E}-02$ & 2,970 \\
\hline \multirow[t]{2}{*}{ BMS09 2B 45-58 (a) } & run 1 & $2.73 \mathrm{E}+02$ & $2.26 \mathrm{E}-01$ & $6.11 \mathrm{E}-05$ & $1.08 \mathrm{E}-03$ & $4.90 \mathrm{E}-02$ & $5.48 \mathrm{E}+03$ & $4.88 \mathrm{E}-02$ & 5,460 \\
\hline & run 2 & $3.38 \mathrm{E}+02$ & $1.71 \mathrm{E}-01$ & $5.87 \mathrm{E}-05$ & $1.65 \mathrm{E}-03$ & $4.78 \mathrm{E}-02$ & $5.35 \mathrm{E}+03$ & 4.77E-02 & 5,340 \\
\hline BMS09 2B 45-58 (b) & & $2.17 \mathrm{E}+02$ & $6.17 \mathrm{E}-01$ & $6.24 \mathrm{E}-05$ & $5.20 \mathrm{E}-04$ & 7.93E-02 & $9.03 E+03$ & 7.87E-02 & 8,950 \\
\hline BMS09 2B 65-71 & & $4.82 \mathrm{E}+03$ & $2.48 \mathrm{E}-02$ & $6.32 \mathrm{E}-05$ & $1.13 \mathrm{E}-01$ & 3.07E-02 & $3.40 \mathrm{E}+03$ & 3.07E-02 & 3,400 \\
\hline \multirow[t]{3}{*}{ 6K1226 R02 } & $\mathrm{a}$ & $1.67 \mathrm{E}+03$ & $5.60 \mathrm{E}-02$ & $6.28 \mathrm{E}-05$ & $2.72 \mathrm{E}-03$ & $4.86 \mathrm{E}-03$ & $5.32 \mathrm{E}+02$ & $4.86 \mathrm{E}-03$ & 530 \\
\hline & $\mathrm{b}$ & $2.54 \mathrm{E}+03$ & $3.53 \mathrm{E}-02$ & $6.22 \mathrm{E}-05$ & $6.85 \mathrm{E}-03$ & $5.14 \mathrm{E}-03$ & $5.62 \mathrm{E}+02$ & $5.13 \mathrm{E}-03$ & 560 \\
\hline & $\mathrm{d}$ & $6.79 \mathrm{E}+02$ & $4.13 \mathrm{E}-02$ & $6.29 \mathrm{E}-05$ & $1.76 \mathrm{E}-03$ & $5.69 \mathrm{E}-03$ & $6.23 \mathrm{E}+02$ & $5.68 \mathrm{E}-03$ & 620 \\
\hline 6K1222 R06-1 & a nm100 & $9.86 \mathrm{E}+01$ & $1.10 \mathrm{E}-01$ & $5.78 \mathrm{E}-05$ & $1.95 \mathrm{E}-04$ & $1.26 \mathrm{E}-02$ & $1.38 \mathrm{E}+03$ & $1.23 \mathrm{E}-02$ & 1,350 \\
\hline \multirow[t]{5}{*}{ 6K1222 R07-1 } & $\mathrm{a}$ all & $1.23 \mathrm{E}+02$ & $6.47 \mathrm{E}-02$ & $5.63 \mathrm{E}-05$ & $6.80 \mathrm{E}-04$ & $2.13 \mathrm{E}-02$ & $2.35 \mathrm{E}+03$ & $2.11 \mathrm{E}-02$ & 2,330 \\
\hline & b nm100 & $2.28 \mathrm{E}+01$ & 7.93E-02 & $6.04 \mathrm{E}-05$ & $4.20 \mathrm{E}-04$ & $8.10 \mathrm{E}-02$ & $9.22 \mathrm{E}+03$ & $8.02 \mathrm{E}-02$ & 9,130 \\
\hline & b nm250 & $2.00 \mathrm{E}+01$ & $2.99 \mathrm{E}-02$ & $6.17 \mathrm{E}-05$ & $4.38 \mathrm{E}-04$ & $3.55 \mathrm{E}-02$ & $3.95 \mathrm{E}+03$ & $3.52 \mathrm{E}-02$ & 3,910 \\
\hline & b mg100 & $6.48 \mathrm{E}+01$ & $1.25 \mathrm{E}-01$ & $6.01 \mathrm{E}-05$ & $1.53 \mathrm{E}-04$ & $1.64 \mathrm{E}-02$ & $1.81 \mathrm{E}+03$ & $1.60 \mathrm{E}-02$ & 1,760 \\
\hline & b mg250 & $3.77 \mathrm{E}+01$ & $1.24 \mathrm{E}-01$ & $6.17 \mathrm{E}-05$ & $4.38 \mathrm{E}-04$ & 7.81E-02 & $8.88 \mathrm{E}+03$ & 7.73E-02 & 8,790 \\
\hline \multirow[t]{4}{*}{ 6K1226 R03 } & a nm250 & $8.44 \mathrm{E}+02$ & $3.65 \mathrm{E}-02$ & $6.24 \mathrm{E}-05$ & $9.91 \mathrm{E}-04$ & $2.30 \mathrm{E}-03$ & $2.51 \mathrm{E}+02$ & $2.29 \mathrm{E}-03$ & 250 \\
\hline & a nm500 & $2.62 \mathrm{E}+01$ & $8.70 \mathrm{E}-03$ & $6.20 \mathrm{E}-05$ & $1.24 \mathrm{E}-03$ & 2.23E-02 & $2.46 \mathrm{E}+03$ & $2.22 \mathrm{E}-02$ & 2,460 \\
\hline & b nm500 & $4.83 \mathrm{E}+02$ & $2.76 \mathrm{E}-02$ & $6.24 \mathrm{E}-05$ & $1.24 \mathrm{E}-03$ & $3.82 \mathrm{E}-03$ & $4.18 \mathrm{E}+02$ & $3.81 \mathrm{E}-03$ & 420 \\
\hline & b mg500 & $1.23 \mathrm{E}+03$ & $4.26 \mathrm{E}-02$ & $6.25 \mathrm{E}-05$ & $1.63 \mathrm{E}-03$ & $3.03 \mathrm{E}-03$ & $3.31 \mathrm{E}+02$ & $3.02 \mathrm{E}-03$ & 330 \\
\hline
\end{tabular}


Table 23.4 (continued)

\begin{tabular}{|c|c|c|c|c|c|c|c|c|c|}
\hline Sample ID & Fraction & ${ }_{(\mathrm{ppb})}^{\mathrm{U}}$ & $\begin{array}{l}\text { Th } \\
(\mathrm{ppb})^{\mathrm{a}}\end{array}$ & ${ }^{234}{ }_{U} /^{238} \mathrm{U}$ & $230 \mathrm{Th} /{ }^{232} \mathrm{Th}$ & ${ }^{230} \mathrm{Th} /{ }^{234} \mathrm{U}$ & $\begin{array}{l}\text { Age } \\
\text { (years) }\end{array}$ & $\begin{array}{l}230_{\mathrm{Th}} \\
234_{\mathrm{U}}^{\mathrm{U}} \\
\text { corr. }^{\mathrm{b}}\end{array}$ & $\begin{array}{l}\text { Age (years) } \\
\text { corr. }\end{array}$ \\
\hline \multicolumn{10}{|l|}{ Snail site } \\
\hline \multirow[t]{3}{*}{ 6K1227 R01 } & anm 1000 & $3.30 \mathrm{E}+00$ & $2.20 \mathrm{E}-02$ & $6.11 \mathrm{E}-05$ & 4.97E-04 & $1.83 \mathrm{E}-01$ & $2.20 \mathrm{E}+04$ & $1.81 \mathrm{E}-01$ & ${ }_{-}{ }^{\mathrm{C}}$ \\
\hline & bnm 250 & $4.17 \mathrm{E}+01$ & $1.29 \mathrm{E}-02$ & $6.25 \mathrm{E}-05$ & $1.50 \mathrm{E}-03$ & 2.49E-02 & $2.75 \mathrm{E}+03$ & $2.48 \mathrm{E}-02$ & 2,740 \\
\hline & anm 500 & $2.87 \mathrm{E}+00$ & $7.06 \mathrm{E}-03$ & $5.61 \mathrm{E}-05$ & $2.11 \mathrm{E}-03$ & $3.10 \mathrm{E}-01$ & $4.05 \mathrm{E}+04$ & $3.09 \mathrm{E}-01$ & ${ }_{-}{ }^{\mathrm{C}}$ \\
\hline \multirow[t]{2}{*}{ 6K1228 R03 } & $\mathrm{a} 01 \mathrm{~nm} 250$ & $1.18 \mathrm{E}+00$ & $1.24 \mathrm{E}-01$ & 5.94E-05 & $1.16 \mathrm{E}-04$ & $6.91 \mathrm{E}-01$ & $1.28 \mathrm{E}+05$ & $6.65 \mathrm{E}-01$ & ${ }_{-}{ }^{\mathrm{C}}$ \\
\hline & b03nm250 & $1.22 \mathrm{E}+01$ & $1.22 \mathrm{E}-02$ & $5.09 \mathrm{E}-05$ & $9.73 \mathrm{E}-04$ & $6.40 \mathrm{E}-02$ & $7.22 \mathrm{E}+03$ & $6.37 \mathrm{E}-02$ & 7,190 \\
\hline
\end{tabular}

Each age has an about $5 \%$ error for samples with $\left({ }^{234} \mathrm{U} /{ }^{232} \mathrm{Th}\right)$ of a few hundreds and a few \% error for samples with $\left({ }^{234} \mathrm{U} /{ }^{232} \mathrm{Th}\right)$ of a few thousands

${ }^{\mathrm{a}} \mathrm{U}$ and $\mathrm{Th}$ abundances are calculated relative to total weight of a sample

${ }^{\mathrm{b}}$ Corrected for possible involvement of silicate minerals derived from sediment

${ }^{\mathrm{c}}$ Samples with * have low $\mathrm{U}$ abundances and they may have suffered alteration events. Their ages were not calculated

\subsection{Discussion}

\subsubsection{Evaluation of Results of Dating Mineralization}

A cross check of results between the ${ }^{230} \mathrm{Th} /{ }^{234} \mathrm{U}$ radioactive disequilibrium dating and ESR dating was examined only for five samples, because minor mineralization of sulfate (barite) made difficult to conduct the ESR dating. Sample "BMS09 2B 65-71" showed fairly good agreement; 3,400 years by the U-Th dating and 3,447 years by the ESR dating. Sample "6K1226 R03" showed agreement with one exception; $250-420$ years with one exceptional age 2,460 years by the U-Th dating, and 180-360 years by the ESR dating. On the other hand, Sample "BMS 07 161-71" showed discrepancy; 15-61 years by the U-Th dating, and 1,110years by the ESR dating. Sample "6K1227R01" showed reversed discrepancy; 2,740 years by the U-Th dating and 110 years by the ESR dating. Sample "6K1228R03" showed largest discrepancy among them; 7,190 years by the U-Th dating and 390years by the ESR dating. Cross checks between the two methods including other data obtained during the TAIGA project are also discussed in other chapter (Kumagai et al. Chap. 5).

It is important to remind that both ${ }^{230} \mathrm{Th} /{ }^{234} \mathrm{U}$ radioactive disequilibrium and ESR dating methods require at least a few grams of sulfide or sulfate mineralized sample. This means that the calculated ages should be considered as homogeneous values, or average ages for sulfide or sulfate minerals included in the sample. As well as in the previous study (Takamasa et al. 2013), mineral textures of the sample in this study suggest that the sulfide and sulfate minerals have repeatedly been precipitated from hydrothermal fluid (Fig. 23.2). The obtained results would correspond not to specific events but to intermediates of duration for continuing mineralization. Or, they may represent apparent average ages of some episodic mineralization events. For example, discrepancy in the age data is found among fractions from Sample "6K1226R03"; 250-2,460 years for Fraction a, 330-420 years for Fraction b, and 4,580 years for Fraction $\mathrm{c}$ by the ESR method. This discrepancy could be interpreted as a result of different incorporation ratio between previously deposited minerals and recently deposited minerals for each analyzed fraction. Moreover, incorporation ratio for sulfide and sulfate minerals can be different because mineralization of these minerals do not occur simultaneously, which would cause discrepancy between the ages obtained by the ${ }^{230} \mathrm{Th} /{ }^{234} \mathrm{U}$ radioactive disequilibrium and ESR dating methods. For example, the discrepancy found in Sample "BMS 07 1 61-71" might be explained as a result of recent mineralization exclusively of sulfides, considering that the ESR age of 1,110 years obtained for this sample well agrees with the U-Th age of the samples collected from deeper portion of the same drilled hole (Samples "BMS07 2B 12-20", "BMS07 2B 27-40", "BMS07 2B 44-55").

As disturbance in highly reliable dating by these two methods, some other factors could be considered. Involvement of silicate minerals would cause a shift of the initial ${ }^{230} \mathrm{Th} /{ }^{234} \mathrm{U}$ ratio away from zero, because we did not eliminate this fraction during the chemical preparation process. We have corrected this effect and the correction was not so large, because ${ }^{230} \mathrm{Th}$ content was high enough in many samples. On the other hand, if the mineralized samples have experienced alteration since the mineralization, it would cause severe problem for ${ }^{230} \mathrm{Th} /{ }^{234} \mathrm{U}$ dating because the apparent age become older by $\mathrm{U}$ loss. We have excluded results from the samples of less than $10 \mathrm{ppm} U$ in this study, however, this threshold was arbitrarily assumed. We cannot exclude possibility for that two samples collected from Snail site (Samples "6K1227R01" and "6K1228R03") suffer from this effect, since most of the fractions from these two samples showed relatively low U content. For the ESR dating, estimation of the dose rate would have uncertainties, because the calculation has assumed several parameters 
Fig. 23.3 Dating results for the core samples from (a) BMS03 and (b) BMS07 a
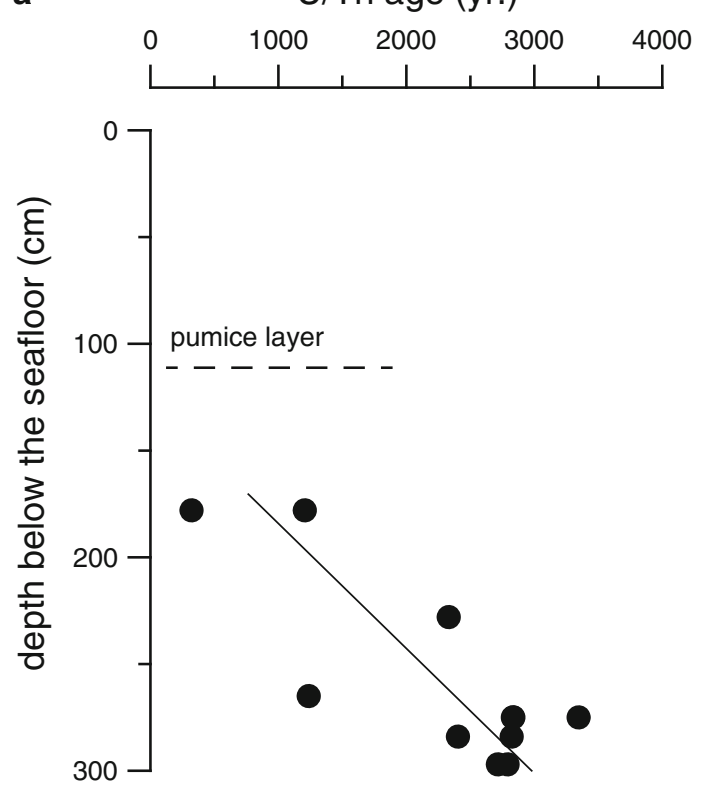

b U/Th age (yr.) $\begin{array}{ccc}0 & 1000 \quad 2000\end{array}$

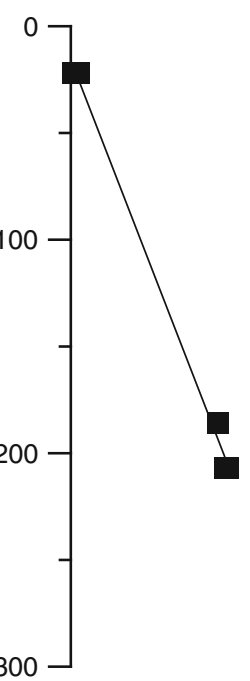

(for example, size and geometry of barite crystals), as discussed in Okumura et al. (2010).

From above factors, it may be difficult to obtain good agreement from one-by-one cross check. At present, we do not have additional data to endorse or withdraw the age data presented here. More detailed studies including consideration for chemical preparations of mineralized samples would be necessary to increase reliability of dating.

In spite of these possible uncertainties, our previous study showed common spatial distribution patterns of ages determined by the two methods, among ten blocks divided from a sulfide crust adjacent to an acitve chimney from the Achaean site (Takamasa et al. 2013). We believe that trend recognized among a series of samples would have high reliability, because they would have similar mineral composition and texture. In this respect, core samples recovered by the BMS drilling from massive sulfide deposits provide a good opportunity to apply dating study.

\subsubsection{Estimation of Growth Rate for Massive Sulfide Mineralization}

Results of dating the massive sulfide ores cored from two drilled holes in the Archaean site are shown in Fig. 23.3. The ${ }^{230} \mathrm{Th} /{ }^{234} \mathrm{U}$ disequilibrium ages are plotted against depth below the seafloor where the core section was assigned. Data points for the BMS03 samples which ages range from 320 to 3,350 years show a crude trend of older ages with depth (Fig. 23.3a). Although the data are somewhat scattered, they do not suggest a hiatus between the measured ages. Linear regression of these 10 data points gives a slope of 17 years per $1 \mathrm{~cm}$. According to this relationship, the depth of a zero age sulfide is calculated as $125 \mathrm{cmbsf}$ (centimeters below the sea floor). We consider this intercept value reasonable, since the top of the massive sulfide was found at $112 \mathrm{cmbsf}$ and only pumiceous materials were found in the shallowest layer by the drilling. Similarly, a slope derived from five data points for the BMS07 samples range from $<100$ to 1,230 years gives an estimated as 6.6 years per $1 \mathrm{~cm}$ (Fig. 23.3b).

As discussed in the previous section, ages of sulfide mineralization should be carefully considered, as they accumulate over a period of time and not instantaneous but constantaneous. We are not confident of estimating growth rates for massive sulfide deposits by simple linear regression. However, the calculated growth rates of $0.59 \mathrm{~mm}_{\text {year }}{ }^{-1}$ for core BMS03 and $1.5 \mathrm{~mm} \mathrm{year}{ }^{-1}$ for core BMS07, respectively, would provide basic age information, when discussing the formation history of this type of mineralization. Previously, we dated a sulfide crust adjacent to an active chimney at the Archaean site, in a water depth of $2,974 \mathrm{~m}$, and estimated its growth rate as $0.12 \mathrm{~mm}_{\text {year }}{ }^{-1}$ (Takamasa et al. 2013). These three estimates of growth rates fall within about a range of one order-of-magnitude, which we believe represent the growth rate of massive sulfide mineralization at this site.

The distribution of ages for all the samples collected from the Archaean Site, including the results of the previous study, is compiled in Fig. 23.4. Here, ages for sulfides both recovered by the BMS drilling and by submersible SHINKAI 6500 are plotted against water depth of the sampling sites. Although the BMS samples were recovered from below the seafloor, their drilled depths were only a few 


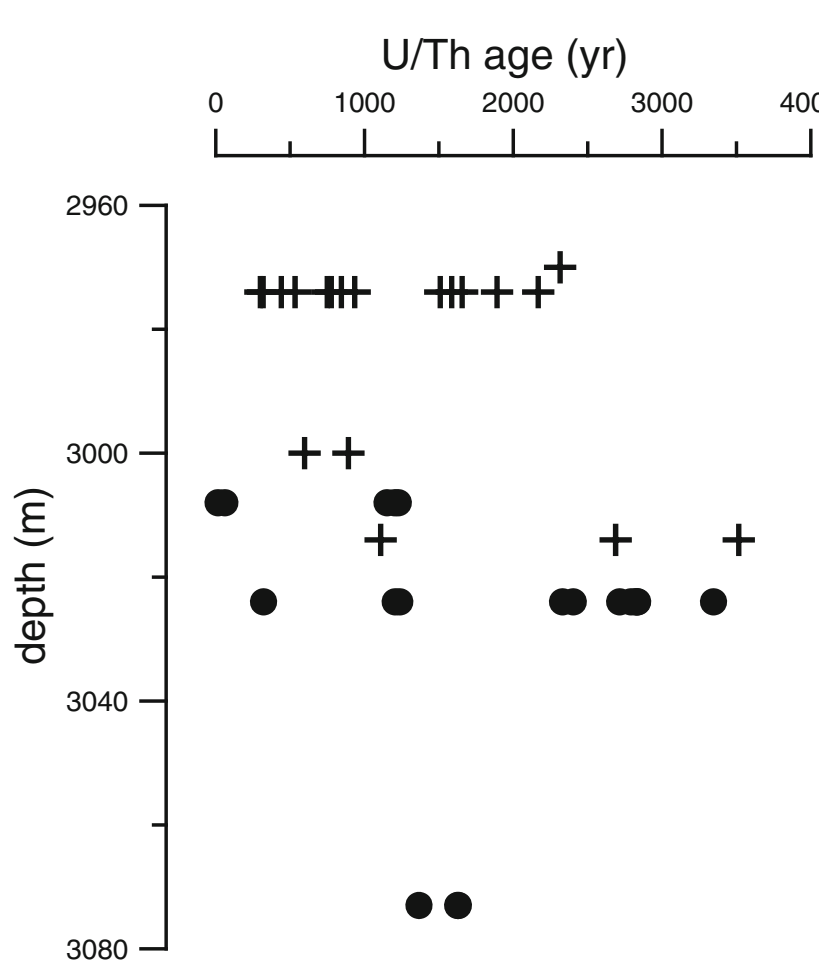

Fig. 23.4 Compilation of dating results for the samples collected from the Archean Site, by the BMS drilling (closed circles) and by the submersible SHINKAI 6500 (cross marks)

meters and not expressed in this figure. Sulfides from the Archaean site range in age from $<100$ to 3,520 years. BMS02 was drilled at a water depth of $3,072 \mathrm{~m}$, that is not on the hydrothermal mound, but on the seafloor adjacent to the mound. Thus, the cored sulfides are attributed to be collapse materials derived from the mound, as Yoshikawa et al. (2012) suggested based on the topography. There is no clear relationship between age and water depth of sampling. Even sulfides collected at water depths shallower than $3,000 \mathrm{~m}$, which is close to the top of the mound, have ages ranging up to 2,310 years. These results are consistent with the hypothesis that seafloor hydrothermal ore deposits grow continuously filling up void spaces. Irrespective, we believe that hydrothermal activity at the Archaean site has a history of $>1,000$ years accumulating massive hydrothermal mineralization all the time.

\subsubsection{History of Hydrothermal Activity in Off-Axis Knolls}

Sulfides collected from the Pika site range in age from 300 to 8,950 years (Table 23.4). The oldest sample occurs within the core samples BMS09. Sulfides collected from the Urashima site range in age from 250 to 9,130 years. Sample "6K1226R03" was a part of an active chimney as young as a few 100 years old, whereas Sample "6K1222R07" is from an inactive chimney and is up to 9,000 years old. Good agreement between the maximum sulfide ages from these two sites would be reasonable, consistent with both sites being located on the same off-axis knoll. Hydrothermal activity at these sites cannot be attributed to magmatic activity related to spreading but to off-axis magmatic activity. Based on estimated local half spreading rate of $13 \mathrm{~mm}$ year $^{-1}$ (Seama and Okino Chap. 20), the Pika and Urashima sites are considered to be located on the oceanic crust of $0.38 \mathrm{Ma}$. It is difficult to continue relationship between hydrothermal activity and heat source magma for such long time duration. On the other hand, a recent seismic refraction survey under the TAIGA project studied 3-D seismic velocity structure in this area, and located a high-velocity region suggesting a cool 'extinct' magma body just beneath the off-axis knoll where these two sites located (Sato et al. Chap. 18). For example, maximum sulfide ages of 9,000 years would be consistent with the time taken for a magma body to cool after emplacement. Hydrothermal activity at the Pika and Urashima sites is therefore considered to be 'late stage' and related to the cooling of a magma body.

The maximum sulfide age from the Archaean site is $\sim 3,500$ years, which is much younger than those from the Pika or Urashima sites. Since no geophysical evidence for a magma body to exist beneath this site, a heat source of hydrothermal activity at the Archaean site could be related to magmatic activity beneath the spreading axis that is located at $\sim 1 \mathrm{~km}$ distance (Seama et al. Chap. 17). Such style of heat supply may contribute to continuous hydrothermal activity at the same mound for $>1,000$ years.

Ages of the sulfide breccia collected from the hydrothermal mound in the Snail site, based on the U-Th dating method, are 2,740 and 7,190 years, while ages for sulfates obtained by the ESR dating method are much younger (110 and 390 years). The U-Th sulfide ages for the Snail site are comparable to those for off-axis sites (Pika and Urashima sites), although we cannot exclude the possibility that these values are affected by hydrothermal alteration.

Geophysical studies during the TAIGA project have shown evidence to support that mantle dynamics and crustal formation in this area are influenced by hydration derived from the subducting slab with accompanying the additional magma supply (Seama et al. Chap. 17). The abundant magma supply is considered to lead to the episodic diking events on the spreading axis and to the off-axis volcanism, both of which supply heat source for hydrothermal activity on the seafloor. The discrete ages from the Snail site may reflect hydrothermal activities fueled by episodic diking events, while the ages from the Pika and Urashima site would be attributed to be related to cooling off-axis magma as mentioned above. In both cases, abundant magma supply in this area would be an important factor 
for long duration of hydrothermal activities, although we need future studies with dating more samples for better understanding the history.

\subsubsection{Comparison with Other Seafloor Massive Sulfide Deposits}

Previous studies have attempted to estimate the age of giant hydrothermal mounds developed within, or just outside, a spreading axis of the mid-ocean ridge. For example, the TAG mound at $26^{\circ} \mathrm{N}$ on the Mid-Atlantic Ridge is located $2.4 \mathrm{~km}$ east of the ridge axis, near the base of the east wall of the rift valley, and is the most well-studied giant hydrothermal mound. Sulfides collected from the TAG mound by submersible dives have yielded ages up to 48,000 years (Lalou et al. 1995), whereas sample recovered by drilling from inside of the mound gave ages from 2,200 to 15,000 years, with exception of two samples dated at $37,000 \pm 1,000$ years (You and Bickle 1998). These studies demonstrated that the distribution of ages correlates with the stratigraphy of hydrothermal mound, with the oldest material found in a middle layer through the center of the deposit. Both groups of researchers suggest that the activity necessary to accumulate sulfide deposits of the TAG mound has not been continuous, but has been interrupted by several periods of extended quiescence. Together with results from our studies, we believe that an order of $10^{4}-10^{5}$ years of continuous hydrothermal activity may be necessary for the formation of giant hydrothermal mounds.

Another comparable set of age data are reported for an off-axial structure on the East Pacific Rise, near $12^{\circ} 43^{\prime} \mathrm{N}$ (Lalou et al. 1985; Fouquet et al. 1996). Sulfides collected from an off-axial seamount (SE Seamount), at located $6 \mathrm{~km}$ east of the spreading axis yielded ages from 11,600 to 30,500 years. This is in contrast to sulfides collected from an active hydrothermal mound $70 \mathrm{~m}$ high and $200 \mathrm{~m}$ in diameter located at $2 \mathrm{~km}$ east of the axis yielded ages of $\sim 2,000$ years. The reported range of sulfide ages are similar to our results, which may suggests a common tectonic condition to form both off-axial structures and hydrothermal mounds. As proposed by these earlier studies, off-axis seamounts are localized areas with high magmatic budget able to drive hydrothermal systems in the same place for long periods of time, enabling sulfide ore mineralization to accumulate. The age data presented in this study would support this hypothesis.

Acknowledgments We are grateful to Captain Morio Endo and crew of the $R /$ V Hakurei-Maru No.2, and also to team leader Tadashi Sato and members of the BMS operation team for their professional skill and careful consideration for collecting core samples during the TAIGA10 cruise. We wish to thank members of SHINKAI 6500 team and crew of the $R / V$ Yokosuka for their skillful support during the YK10-11 cruise.
We are grateful to the staff of Kyoto University Research Reactor (KUR) for neutron irradiation of the samples used for laser fusion ${ }^{39} \mathrm{Ar}^{40} \mathrm{Ar}$ dating, and also to the staff of Takasaki Advanced Radiation Research Institute, Japan Atomic Energy Agency (JAEA) for gamma ray irradiation of the sample used for ESR dating. This study was partially supported by the "TAIGA project," which was funded by a Grant-in-Aid for Scientific Research on Innovative Areas (\#20109004) from the Ministry of Education, Culture, Sports, Science and Technology (MEXT), Japan. A part of this study was supported also by the Inter-University Program for the Joint Use of JAEA Facilities. This manuscript benefited from constructive comments from Tatsuo Nozaki and Cornel de Ronde.

Open Access This chapter is distributed under the terms of the Creative Commons Attribution Noncommercial License, which permits any noncommercial use, distribution, and reproduction in any medium, provided the original author(s) and source are credited.

\section{References}

Baksi AK (1999) Reevaluation of plate motion models based on hotspot tracks in the Atlantic and Indian oceans. J Geol 107:13-26

de Ronde CEJ, Massoth GJ, Butterfield DA, Christenson BW, Ishibashi J, Ditchburn RG, Hannington MD, Brathwaite RL, Lupton JE, Kamenetsky VS, Graham IJ, Zellmer GF, Dziak RP, Embley RW, Dekov VM, Munnik F, Lahr J, Evans LJ, Takai K (2011) Submarine hydrothermal activity and gold-rich mineralization at Brothers Volcano, Kermadec arc, New Zealand. Miner Deposita 46:541-584

Ditchburn RG, de Ronde CEJ, Barry BJ (2012) Radiometric dating of volcanogenic massive sulfides and associated iron oxide crusts with an emphasis on ${ }^{226} \mathrm{Ra} / \mathrm{Ba}$ and ${ }^{228} \mathrm{Ra} /{ }^{226} \mathrm{Ra}$ in volcanic and hydrothermal processes at intraoceanic arcs. Econ Geol 107:1635-1648

Fouquet Y, Knott R, Cambon P, Fallick A, Rickard D, Desbruyeres D (1996) Formation of large sulfide mineral deposits along fast spreading ridges. Example from off-axial deposits at $12^{\circ} 43^{\prime} \mathrm{N}$ on the East Pacific Rise. Earth Planet Sci Lett 144:147-162

Hyodo $\mathrm{H}$ (2008) Laser probe ${ }^{40} \mathrm{Ar} /{ }^{39} \mathrm{Ar}$ dating: history and development from a technical perspectivem. Gondwa Res 14:609-616

Jamieson JW, Hannington MD, Clague DA, Kelley DS, Delaney JR, Holden JF, Tivey MK, Kimpe LE (2013) Sulfide geochronology along the Endeavour segment of the Juan de Fuca Ridge. Geochem Geophys Geosyst 14. doi:10.1002/ggge20133

Lalou C, Brichet E (1987) On the isotopic chronology of submarine hydrothermal deposits. Chem Geol 65:197-207

Lalou C, Brichet E, Hekinian R (1985) Age dating of sulfide deposits from axial and off-axial structures on the East Pacific Rise near $12^{\circ} 50^{\prime} \mathrm{N}$. Earth Planet Sci Lett 75:59-71

Lalou C, Reyss J-L, Brichet E, Rona PA, Thompson G (1995) Hydrothermal activity on a $10^{5}$-year scale at a slow-spreading ridge, TAG hydrothermal field, mid-Atlantic Ridge $26^{\circ} \mathrm{N}$. J Geophys Res 100:17855-17862

McDougall I, Harrison TM (1999) Geochronology and thermochronology by the ${ }^{40} \mathrm{Ar} /{ }^{39} \mathrm{Ar}$ method. Oxford University Press, Oxford, p 269

Nakamura K, Toki T, Mochizuki N, Asada M, Ishibashi J, Nogi Y, Yoshikawa S, Okino K (2013) Discovery of a new hydrothermal vent site in the Southern Mariana Trough based on geophysical surveys using the AUV Urashima. Deep Sea Res I 74:1-10

Okumura T, Toyoda S, Sato F, Uchida A, Ishibashi J, Nakai S (2010) ESR dating of barite in chimneys deposited from hydrothermal vents. Geochronometria 37:57-61 
Takamasa A, Nakai S, Sato F, Toyoda S, Banerjee D, Ishibashi J (2013) U-Th radioactive disequilibrium and ESR dating of a barite-containing sulfide crust from South Mariana Trough. Quater Geochronol 15:38-46

Toyoda S, Sato F, Banerjee D, Ishibashi J (2011) Characteristics of the radiation induced ESR signals in barite. Adv ESR Appl 27:4-6

Wanke M, Portnyagin M, Hoernle K, Werner R, Hauff F, van den Bogaard P, Garbe-Schöberg D (2012) Bowers Ridge
(Bering Sea): an Oligocene-early Miocene island arc. Geology 40:687-690

Yoshikawa S, Okino K, Asada M (2012) Geomorphological variations at hydrothermal sites in the southern Mariana Trough: relationship between hydrotherm alactivity and topographic characteristics. Mar Geol 303-306:172-182

You C-F, Bickle MJ (1998) Evolution of an active sea-floor massive sulphide deposit. Nature 394:668-670 